\title{
Mountain Forests Ecology, Anthropogenic Degradation and Ways to Improve Institute of Erosion and Irrigation ANAS
}

\author{
ZH Aliev* \\ Institute of Erosion and Irrigation of Azerbaijan National Academy of Sciences, Azerbaijan
}

Submission: October 04, 2016; Published: October 27, 2016

*Corresponding author: ZH Aliev, Institute of Erosion and Irrigation of Azerbaijan National Academy of Sciences, Azerbaijan.

Abstract

When properly administered process low-intensity irrigation can not only dramatically reduce the consumption of water for irrigation from / crops, but also to provide the necessary climate for plants and supply of water and fertilizer in the required amount directly into the zone korneobitaniya that promotes early entry into fruiting plants and increase productivity while reducing water per unit of yield and reduce production costs.

Keywords: Low-intensity; Automation; Irrigation technology; Regulatory; Background; Bank data; The controller; Connection, Object; Sensors

\section{Ecology of Mountain Forests}

Forest cover of the country the world's forest cover $(18.5$ Russian Federation, Canada) 0.9\%, Brazil -11,8) $0.03 \%$ of the total. Geographic and environmental factors biosferinin was a part of the forest plays an important role in nature like [1].

Forests protect soil and water resources, soil erosion by preventing the water from the watering, who declared them clean and quiet rivers, fountains, water reserves fills little-runner river water pollution and protect it from adjusting it reduces or prevents flood events. Compared with other countries, our republic has little woody plants higher than $11.4 \%$ of the area is covered by forest [2]. Along with all this, it should be noted that, at present, 261 hectares of forest, the army, and they are under the control of our territory was occupied by Armenian Bakarlar. Although a small area, rich in forests of trees and shrubs. Here is the cover of more than 450 wild trees and shrubs grow. 70 of them are endemic species do not grow anywhere else republic. Despite the destruction of forests all over the world, but the church was full of agricultural crops and pastures are transformed into forests, large areas are exposed to fire. At present, the planet will be - deforestation process.

The destruction of the forest by local, regional and global levels, climate change has a negative impact on the biodiversity of flora and fauna, cloud reduces the biosphere sustainability, flood, flood and water erosion, strong winds, causes of desertification lillenmesine. The mountain forests of the Caucasus and the Lesser Caucasus and Talysh Mountains remained. These forests are more than 90 percent of the area is covered with forests in the country. The unique features of each of these regions are in the woods.

The spread of forests and environmental factors play a major role in the formation of the mountain. It rose to a height above sea level; climate (temperature, precipitation and humidity) and soil productivity due to the change in the composition of the forests are changing. Prilipko 3 divides in the country with particular emphasis on forest zone. Lower mountain forest zone, according to the author of 500-600 m above sea level, covers an area of 800-900 m. Our studies have shown that low-Balkan region west of the Great Caucasus mountain forest zone begins $350 \mathrm{~m}$. High mountain forest zone from $900 \mathrm{~m}$ above sea level, united in 1800-1900 m. Here are purely dominated by beech forests of beech and Velesle mixed. The upper mountain forest zone, more than 1,800 meters above sea level, the percentage of sub-alpine zone holds up [3].

In many places the border of the natural climate of the forest through the artificially reduced from 1900-2100 m above 
the forest zone, sometimes it was destroyed. The eastern zone of the prevailing oak tree species, in addition, birch, beech, birch, mountain garagadji, juniper bushes and so on. Can be found since ancient times, people have made extensive use of forest resources to meet their needs. However, the nature of those times, including the intervention of the forest's natural complexes are simple ways to change the process was going very slowly.

\section{Anthropogenic Degradation}

With increasing demand for forest resources of the people of the forest-tezniki intervention progress accelerated. Recently, the forest resources are widely used in the majority of the national economy. Therefore, degraded forests, and the area is undergoing rapid decreases from year to year. Available survey data indicate that the area is covered with forests in the country at the beginning of the last century, $14.5 \%$ of the total area (1915) per share (Forested percent). At present, the figure is $11 \%$. As you can see forests in the area has decreased significantly in the short term.

At the beech forests of the southern slope of the Greater Caucasus Balkan region is 47.6. Balkan in forestry in (1938). According to the structure of the forest with beech forests of the higher interest rates $(65.2 \%)$, in of the lower forests qlxmasina (200-400 m, sometimes more) has been caused. Isotherm conditions of $100 \mathrm{C}$ in July in the Caucasus (Azerbaijan Republic) of forest natural (climate) should be above the upper border of the $2500-2600 \mathrm{~m}$. But, of course, the upper limit of the forest as a result of anthropogenic factors in the lower (1900-2100 $\mathrm{m}$ ) is dropped. In 1984 a significant decrease in forest structure and beech forests in the period accounted for $47.6 \%$ of the area covered by forest made. Such a decrease in the forests of beech Kate (Balakencayi basin) during the period of intense activity of Balkan cutting plant (mainly for the production of parquet) beech forests have been cut due to the destruction.

As can be seen in a short period of time for use during the Balkan forestry tree beech forests having sex has decreased by $17.6 \%$. Forestry beech forests dried by a sharp $26 \%$ of the area are covered by forest. The beech forests in view of the reduction of humidity have been decreased. Such a situation was little doubt the role of the relief and anthropogenic factors. Sahibs Kurmukchay Ilium and villages in the basin since ancient times by the destruction of forests, fields, agriculture (both in agriculture and cattle breeding) use, beech forests, hornbeam, juniper and other trees to replace can be considered a major factor in this respect. Recently, systematic destruction of forests and grazing under the influence of anthropogenic factors the upper limit.

\section{Ways to Improve the Mountain Forests}

Mountain forests under the influence of anthropogenic factors in the areas of transformation and restoration of the following actions are recommended to improve [4].
1. The upper limit of the forest in order to restore the forest before the 100-200 m wide protective strip on the border of the above (buffer zone) to pay, there should be a ban on cattle grazing. According to the rocky slopes scoured the forest planting activities in case of an ordinary candle, juniper, lesswashed hillside birch, oak, pear, trautvetter, birch and hazelnut month shall prevail. Alpine and sub-alpine pastures and grazing pasture violated Poor circulation system to allow the vegetation to improve cattle pasture. It is recommended for use as an eroding hillside meadow in southern areas. The upper forest belt (1800-2000 m), distributed sparse oak, birch forests, cattle grazing stopped and oak seeds in sahecik should basdir soften the soil. 1700-1900 m-dominated sparse in Meselik peanuts should be banned cattle grazing. In Sahecik land yumsaldilaraq basdirmali peanut seeds.

2. Medium steep slopes of the mountain-forest zone (1200$1800 \mathrm{~m}$ ), broken down doluluql the hornbeam-beech forests and illegal logging, cattle grazing should be prohibited. The average altitude of the forest areas near settlements and along the roads less prone slopes (10-12) disrupted a tenuous twoyear beech groves of beech, hornbeam planting seedlings need of reclamation.

3. Asagi mountain-forest zone teeth derivative-type semiprecious oriental hornbeam trees to restore the forest area to protect the herd, the second grade trees and shrubs should be done gradually from the ground, $1 \mathrm{x} 1,1 \mathrm{x} 2$ meters sahecik to or tilled strips of oak seeds buried. Forestry measures should be continued in the following years.

Lower mountain forest zone (600-900 meters) from the individual trees of different kinds of fruit and berry bushes and wild trees, grafting cuttings hemimezofit in siblek services through the forest to create gardens. Lower mountain forest zone (600-900 meters) qara tiken, iydeyarpaq pear, barberry, Meadowsweet meadow prevailing in the Crimean pine and pine hemikserofit siblekler rebuild the plug, fruits and berries in the forest-garden set up by the prevailing service areas.

Lower mountain forest zone and the mountainous area of eroded land and lakes furigana, (400-1000 m) bozqurlarda or semi-deserts and pine forests forced the Crimean pine or pistachio, almond,

increase, iydeyarpaq pear and pine forests of plug burglar create.

Doctor of the Institute of Geography of ANAS, prof. Mahmoud Khalil reference to the valuable research results have shown that the north-western slope of the Greater Caucasus mountain forest in the upper zone of Khizi region as a result of anthropogenic impacts in excess of 60 meters in the eastern forests of oak was destroyed completely. Mountain (2207 meters) on the southern slope of the individual and the group now can be found in the ends of oak Iraq. 
Basin Altiaghaj people in low- and middle-stone-forest zones in the beech forests significantly reduced economic activity and in its corn fields, meadows and oak and meadow steppe still dusmuslasm is freebies conditions dominated from or derivative type Iberia has replaced the broken reseller. Khizi region known at the National Academy of Sciences Institute of Erosion and Irrigation DAC-forest zone of the lower profile bushes against the backdrop of moderately eroded ordinary pine, cream pine, chestnut leaf oak, elm, preventing soil erosion through the use of forest lands, expansion of forest areas and improve the research work carried out in the national economy, of which the results of the large-scale application in the country itself is of particular quantity [5].

\section{References}

1. Aliev BH, Aliev ZH (1999) Others Techniques and technology few intensive irrigations in condition of the mountain region Azerbaijan. Publishers “Elm”, Baku, pp. 220.
2. Aliev BH, Aliev ZH (2007) The premises about the most important problem of the agriculture in provision water resource mountain and foothill regions Azerbaijan. J AAS, \#1-3, Baku, pp. 179-182.

3. Aliev BH, Aliev ZH (1999) The premises of the decision of the problems moisture provides agriculture cultures production in mountain and foothill region Azerbaijan. The works SRI «Erosions and Irrigations". Baku, pp. 125-129.

4. Guseynov NM (1969) Ways to improve the efficiency of use of irrigated land, improved technologies and methods for irrigation of agricultural crops in Azerbaijan. Report on the degree of competition. C. c. D. on the basis of works, Baku s. pp. 214-230.

5. (2002) International Center C / X Research in the dry in the Dry Areas (ICARDA) Irrigation regime and monitoring equipment. In: U Umarova \& A Karimov (Eds.), Taraz: IC "AQUA" pp. 128.

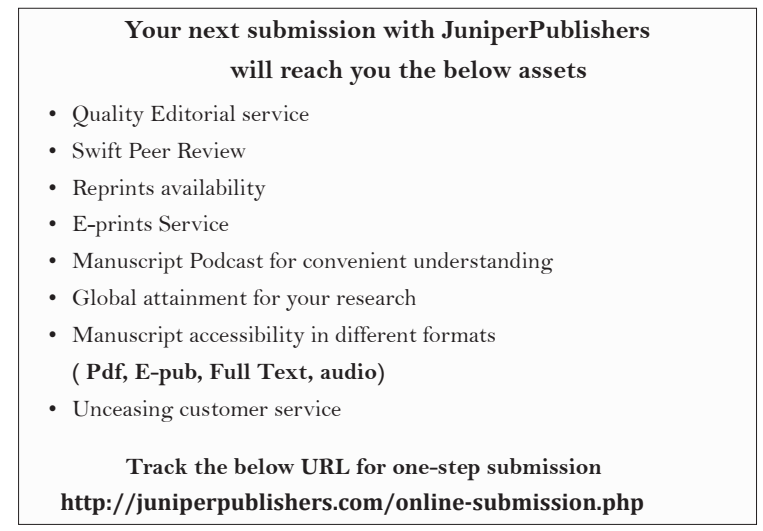

